\title{
Biological indices applied to benthic macroinvertebrates at reference conditions of mountain streams in two ecoregions (Poland, the Slovak Republic)
}

\author{
Iga Lewin - Izabela Czerniawska-Kusza • \\ Krzysztof Szoszkiewicz • Agnieszka Ewa Lawniczak • \\ Szymon Jusik
}

Received: 27 September 2012/Revised: 28 December 2012/Accepted: 13 January 2013/Published online: 30 January 2013

(C) The Author(s) 2013. This article is published with open access at Springerlink.com

\begin{abstract}
The study was carried out from 2007 to 2010 in two ecoregions: the Carpathians and the Central Highlands. The objectives of our survey were to test the existing biological index metric based on benthic macroinvertebrates at reference conditions in the high- and mid-altitude mountain streams of two ecoregions according to the requirements of the EU WFD and to determine which environmental factors influence the distribution of benthic macroinvertebrates. Our results revealed statistically significant differences in the values of the physical and chemical parameters of water as well as the mean values of metrics between the types of streams at the sampling sites. RDA analysis showed that the temperature of the
\end{abstract}

Handling editor: P. Nõges

I. Lewin $(\bowtie)$

Department of Hydrobiology, Faculty of Biology and Environmental Protection, The University of Silesia,

9 Bankowa Street, 40-007 Katowice, Poland

e-mail: iga.lewin@us.edu.pl

\section{Czerniawska-Kusza}

Department of Land Protection, Faculty of Natural and Technical Sciences, Chair of Monitoring and Spatial Management, Opole University, 22 Oleska Street, 45-052 Opole, Poland

K. Szoszkiewicz · A. E. Ławniczak · S. Jusik Department of Ecology and Environmental Protection, Faculty of Land Reclamation and Environmental Engineering, Poznań University of Life Sciences, 94C Piątkowska Street, 60-649 Poznań, Poland water, $\mathrm{pH}$, conductivity, the stream gradient, values of the HQA index, and altitude were the parameters most associated with the distribution of benthic macroinvertebrate taxa and the values of the metrics. The values of biological indices should be considered according to the stream typology including altitude and geology. At the reference conditions, the suggested border values of biological indices are very harsh. The values of the biological indices of most sampling sites did not correspond to the requirements of the high status in rivers. The streams at altitudes above $1,200 \mathrm{~m}$ a.s.l. should be treated as another river type and new reference values should be established.

Keywords Benthic macroinvertebrates .

Reference conditions - Biological indices .

Water Framework Directive $\cdot$ Mountain stream

\section{Introduction}

According to the requirements of the European Union Water Framework Directive (EU WFD), the composition and abundance of benthic invertebrate fauna, other than aquatic flora or fish fauna, constitutes one of the quality elements for the classification of the ecological status of rivers (Directive, 2000/60/EC). The hydrological regime, morphological conditions or the physical and chemical parameters of water are supporting elements for the biological data. However, because Member States establish monitoring systems 
for estimating the values of the biological elements, the methods for the evaluation of the ecological status of rivers are different (Sandin \& Johnson, 2000a; Vlek et al., 2004; Gabriels et al., 2005; Bona et al., 2008; Lock et al., 2011). The aims of the intercalibration procedure undertaken were to identify and to resolve significant inconsistencies between the national programs and the quality class boundaries established by Member States (Birk \& Hering, 2006). In Poland, the Macrophyte Method for Rivers (Szoszkiewicz et al., 2010a) is an official monitoring approach for rivers. This method, which includes calculating the Macrophyte Index for Rivers (MIR), is consistent with the majority of European methods, e.g., the Mean Trophic Rank (MTR), the Macrophyte Biological Index for Rivers (IBMR), and the EU-STAR project methodology. The value of the MIR index reflects river degradation, especially in terms of eutrophication. However, the official monitoring approach for rivers based on benthic macroinvertebrates, is still in the preparation stage (Dz. U., 2011).

The ecological status of rivers is defined through the comparison of monitoring sites with unimpacted reference conditions that are specific to that river type. The reference conditions must be of a high ecological status and thus show no, or only very minor, evidence of distortion (human impact) (Directive, 2000/60/EC). These reference conditions are related to e.g., the hydrological, physical, and chemical criteria (river morphology, habitat condition, point and diffuse sources of pollution, land use or the occurrence of invasive species). The reference conditions include very minor disturbances which means that human pressure is allowed as long as there are no, or only very minor, ecological effects. Thus, the Member States are obligated to establish the reference conditions for different types of surface waters in relation to the European ecoregions (Clarke et al., 2003; Davy-Bowker et al., 2006; Verdonschot, 2006). Our studies focus on testing the biological index metric based on benthic macroinvertebrates at reference conditions in mountain streams. We expected to find the reference condition in headwater streams, as most of them are situated within national parks, e.g., the Babia Góra National Park (one of the first Biosphere Reserves in the world), the Gorce National Park and the Tatra UNESCO Biosphere Reserve, which covers two national parks, e.g., the Tatra National Park (Poland) and the Tatranský Národný Park (the Slovak Republic). There are areas in the strictly protected
National Park zone where little or no commercial forestry operations have been carried out for the last 50-150 years. Natural woodland processes have been encouraged there, and as a result, mosses and lichens are luxuriant (Raven et al., 2011). The diversity of geological composition, surface relief, soil properties, and harsh climatic conditions of the Tatras gave rise to fauna and flora of a special mountain and alpine character.

According to the requirements of the WFD, macroinvertebrates are a group commonly used for assessing water quality. In streams, benthic macroinvertebrates reflect e.g., the anthropogenic perturbation, organic pollution, acidification, or other types of stream degradation (Tripole et al., 2008; Mykrä et al., 2012). The biological indices (metrics) are widely recommended and appear to be a valuable tool in monitoring macroinvertebrate response to both unimpacted (reference conditions) and anthropogenic disturbances in rivers throughout the European ecoregions (Aqem, 2002; Rawer-Jost et al., 2004; Semenchenko \& Moroz, 2005; Šporka et al., 2006; Leunda et al., 2009; Šporka et al., 2009; SánchezMontoya et al., 2010; Torrisi et al., 2010). However, existing studies on macroinvertebrate biological metrics in unimpacted European mountain streams are still limited.

The objectives of our survey were to test the existing biological index metric based on benthic macroinvertebrates at reference conditions in the high- and midaltitude mountain streams of two ecoregions according to the requirements of the EU Water Framework Directive; to analyze whether the values of the metrics varied in streams within and among the ecoregions in relation to geology, the physical and chemical parameters of the waters and to determine which environmental factors influence the distribution of benthic macroinvertebrates in the different types at highland and mountain streams. We hypothesize that the values of the biological indices (metrics) will properly reflect the ecological status of the water and will correspond to the requirements of the high status of reference conditions in rivers.

\section{Materials and methods}

Study area

The study was carried out from 2007 to 2010 (June, July) in two ecoregions established by Directive (2000/60/EC), e.g., in the Carpathians (ecoregion no 10) and in the Central Highlands (ecoregion no 9). 
Because ecoregions 9 and 10 are not homogeneous in terms of geological origin, sampling sites were selected within natural physico-geographical regions (Kondracki, 2002) in Poland and in part of the Slovak Republic (Fig. 1) (Table 1). In total, 58 potential reference sampling sites that were likely to be of a high ecological status and that were situated in the headwater of mountain streams at mid- and highaltitudes were selected. Most of the sampling sites were situated within national parks or reserves, e.g., the Babia Góra National Park (one of the first Biosphere Reserves in the world), the Gorce National Park, the Tatra National Park, the Tatranský Národný Park in the Slovak Republic, the Pieniny National Park, and the nature reserve "Wisła" (the Silesian Beskids). With the exception of the Babia Góra Biosphere Reserve, the reference sites were situated on the territory of the Tatra UNESCO Biosphere Reserve, which covers two national parks, e.g., the Tatra National Park (Poland) and the Tatranský Národný Park (the Slovak Republic).

\section{Water and benthic macroinvertebrates}

Samples of water were collected from each sampling site immediately before the sampling of macroinvertebrates. Analyses of the physical and chemical parameters of the water, e.g., conductivity, temperature, and $\mathrm{pH}$ were measured in the field using a portable $\mathrm{pH} / \mathrm{EC} /{ }^{\circ} \mathrm{C}$ meter HI $9811-5$ by Hanna Instruments and dissolved oxygen with an oxygen meter CO-401 by Elmetron. Analysis of ammonium, nitrite, nitrate, and phosphate concentrations in the water and alkalinity were carried out using colorimetric and titrimetric methods using meters and reagents by Hanna Instruments or Merck.

The samples of benthic macroinvertebrates were collected using a hand net with a square frame $\left(25 \mathrm{~cm} \times 25 \mathrm{~cm}=\right.$ sampling surface of $\left.625 \mathrm{~cm}^{2}\right)$ and mesh size below $500 \mu \mathrm{m}$ according to the methodology of Aqem (2002), Bis (2006), and Bis \& Wenikajtys (2006). At each sampling site, a total of 20 replicates (subsamples) was taken from all major habitat types in the reach (sampling surface of $1.25 \mathrm{~m}^{2}$ ) using a hand net. In addition, benthic macroinvertebrates were collected from the softer bottom sediments among boulders and blocks using a core sampler (diameter $5 \mathrm{~cm}$, sampling surface of $19.6 \mathrm{~cm}^{2}$ ). At each sampling site, 20 samples were collected using a core sampler. In the field, all collected material was preserved in $75 \%$ ethanol and then brought back to the laboratory in plastic containers. In the laboratory, the samples were sieved with a $0.23 \mathrm{~mm}$ mesh net and then sorted under a stereoscopic microscope. The benthic macroinvertebrates were counted and identified to the family or genus level (Rozkošný, 1980; Kołodziejczyk \& Koperski, 2000; Eggers \& Martens, 2001; Glöer, 2002; Glöer \& MeierBrook, 2003).

The following metrics were calculated (Aqem, 2002):

1. Density.

The density of benthic macroinvertebrates was estimated as the number of individuals per square meter.

2. The total number of macroinvertebrate taxa.

3. The BMWP(PL)—Biological Monitoring Working Party index adapted to the Polish conditions. The benthic macroinvertebrates were identified to the family or genus level in accordance with the requirements of the BMWP(PL) methodology. Heptageniidae were identified to the genus level, e.g., Epeorus Eaton, 1868, Rhitrogena Eaton, 1881, Ecdyonurus Eaton, 1868, and Heptagenia Walsh, 1863. All Oligochaeta were considered as one family.

4. The ASPT (Average Score per Taxon).

The ASPT is the value of BMWP divided by the number of BMWP families present in the taxa list.

5. The diversity index $d$ (a modified version of the Margalef index):

$\mathrm{d}=\mathrm{S} / \log \mathrm{N}$, where,

$\mathrm{S}$ - is the number of taxa (families),

$\mathrm{N}$-is the density of macroinvertebrates (individuals per square meter).

6. The index of \%EPT (\%EPT $=$ sum of all individuals of Ephemeroptera, Plecoptera, and Trichoptera divided by the sum of all collected macroinvertebrates $100 \times$ ).

The water and benthic macroinvertebrate surveys were supported by both a hydromorphological and macrophytes assessment (hydromorphological and biological elements) at the same sampling sites.

Hydromorphological survey

The hydromorphological study was carried out according to the River Habitat Survey (RHS) methods 
Fig. 1 Location of the study area (ecoregions 9 and 10). Abbreviations: 10 - ecoregion no 10 (the Carpathians); ZB-the Zywiec Beskids; BG-the Babia Góra Massif; G-the Gorce Mts.; BS—-the Sadecki Beskids; SB-the Silesian Beskids; HT-the Eastern (High) Tatra Mts.; P-the Pieniny Mts. 9-ecoregion no 9 (the Central Highlands); KV-the Kłodzko Valley; K-the Karkonosze Mts.; GO-the Góry Opawskie Mts

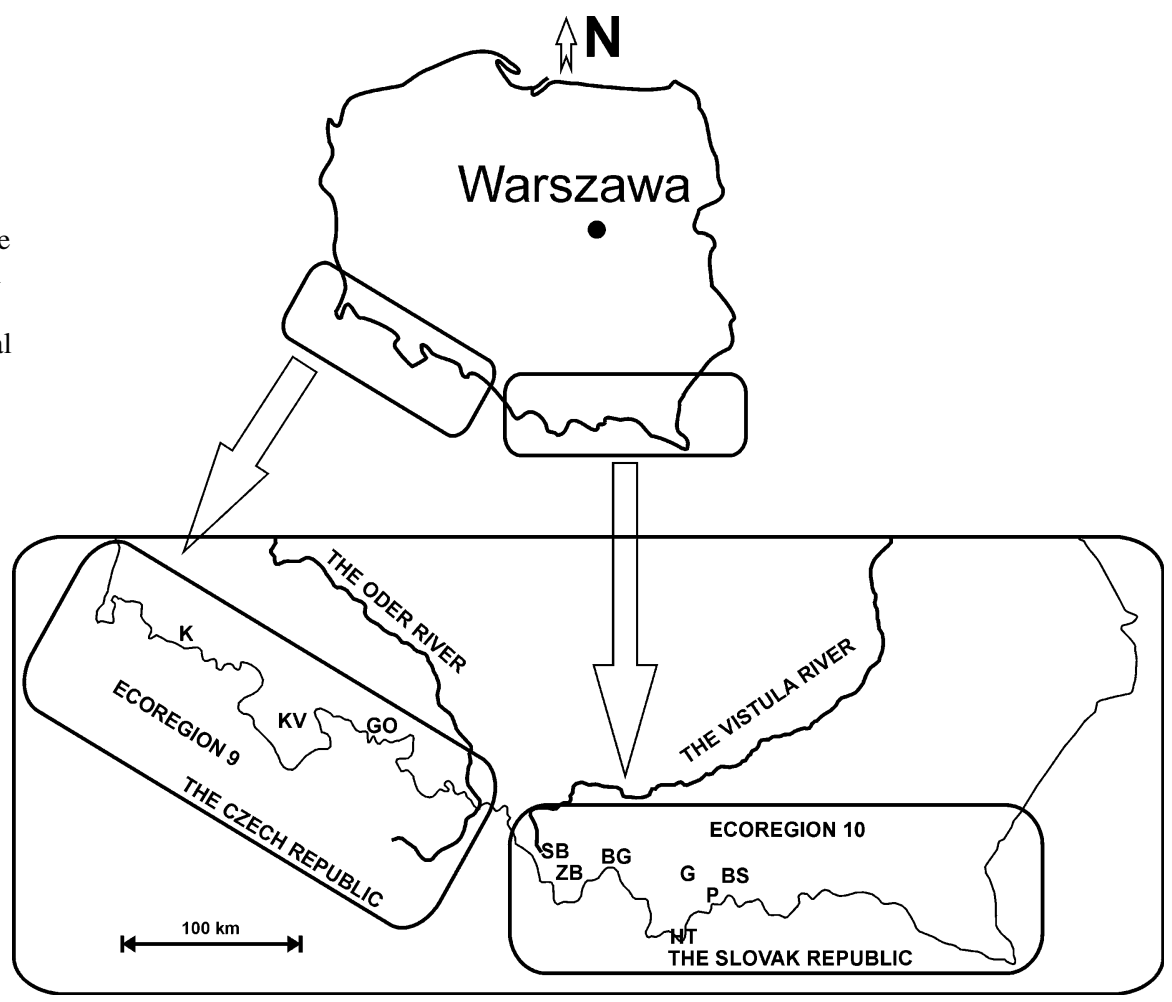

adapted to the Polish conditions (Environment Agency, 2003, 2007). The River Habitat Survey (RHS) is a method designed to characterize and assess the physical structure of streams and includes e.g., the channel substrate (predominant substrate: bedrock, boulder, cobble, gravel/pebble, sand, silt), the flow type (category: free fall, chute, broken standing waves, unbroken standing waves, chaotic flow, rippled, upwelling, smooth, not visible), altitude, and the stream gradient. Based on the results of the hydromorphological survey, two indices were calculated: the Habitat Modification Score (HMS) and the Habitat Quality Assessment (HQA). Low values of the HMS indicate limited artificial modification of watercourses, whereas higher values indicate a high habitat modification. High values of the HQA indicate the extensive presence of a number of natural river features (Szoszkiewicz et al., 2010b).

\section{Macrophyte surveys}

The macrophyte surveys were carried out according to the Macrophyte Methods for Rivers adapted to the Polish conditions (Szoszkiewicz et al., 2010a). The total cover (\%) by aquatic macrophytes (mainly mosses and algae) of the stream beds was estimated.
The Macrophyte Index for Rivers (MIR) was calculated based on the results of the survey.

Selection of reference sites

The initial field recognition and choice of reference sites took place before the fundamental field survey. The reference sites were chosen according to the EU WFD criteria: the geology, the catchment area with respect to its physical, chemical, and biological attributes, altitude (mid-altitude 200-800 m a.s.l., high-altitude $>800 \mathrm{~m}$ a.s.l.), the pristine nature of the headwater streams as proved by physical and chemical analyses and the absence of any obvious sources of pollution, alien species as well as little or no commercial forestry operations (Directive, 2000/60/EC; Nijboer et al., 2004; Baattrup-Pedersen et al., 2009). Reference sites were located in wilderness and deep forests, within a distance of many $\mathrm{km}$ from the nearest hiking trails, marked tracks and paths and above shelters and huts.

In the High Tatra Mts. and the Babia Góra Massif within $50 \mathrm{~m}$ from the bank top, coniferous or mixed woodlands as well as dwarf pine Pinus mugo Turra (legally protected in Poland) and rock or scree above the tree line were the predominant land use. On the territory 


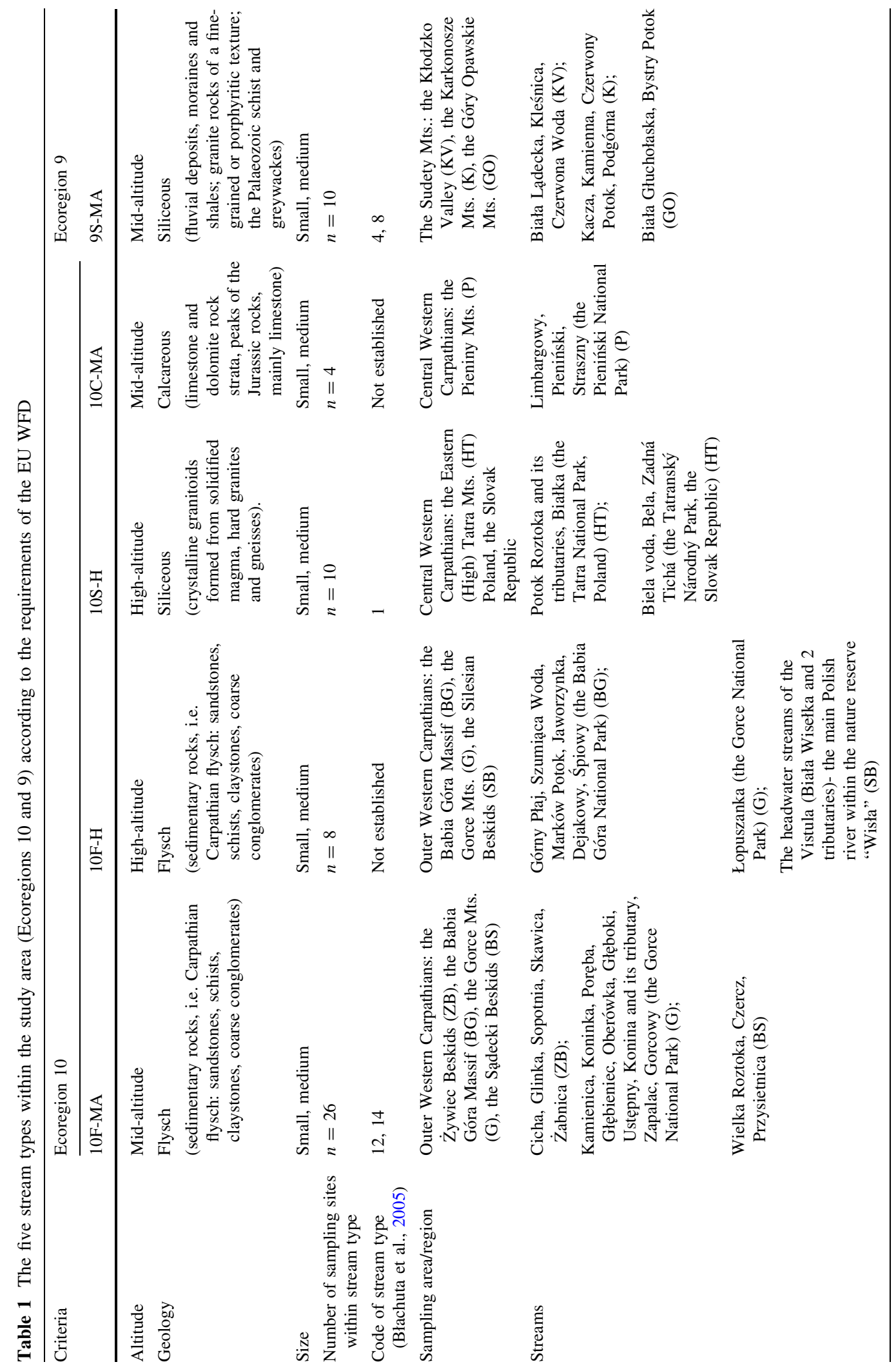


of the Tatra UNESCO Biosphere Reserve, which covers two national parks, e.g., the Tatra National Park (Poland) and the Tatranský Národný Park (the Slovak Republic), about $70 \%$ of land is forested. Spruce Picea abies (L.) H. Karst. is commercially exploited outside the strict nature protection areas, but is managed for conservation elsewhere. There is little cultivation above $800 \mathrm{~m}$ and no livestock grazing above the tree line. Within the protected National Park zone there are areas where little or no commercial forestry operations (e.g., logging) have been carried out for the last 50-150 years. Thus, natural woodland processes have been encouraged and as a result, mosses and lichens are luxuriant (Raven et al., 2011).

The typologies of the streams were taken according to their adaptation to Polish conditions (Błachuta et al., 2005) based on the EU WFD requirements. Five stream types were selected within the study area: a flysch stream at mid-altitude in ecoregion 10 (10F-MA), a flysch stream at high-altitude in ecoregion $10(10 \mathrm{~F}-\mathrm{H})$, a siliceous stream at high-altitude in ecoregion $10(10 \mathrm{~S}-\mathrm{H})$, a calcareous stream at midaltitude in ecoregion 10 (10C-MA), and a siliceous stream at mid-altitude in ecoregion 9 (9S-MA) (Table 1).

Reference conditions were defined using the following criteria (Sánchez-Montoya et al., 2009):

(1) hydromorphological elements:

values of the HMS $<8$ and the HQA $>47$ (Walker et al., 2002; Szoszkiewicz et al., 2010a);

(2) biological elements:

values of the MIR index which were established by the Polish law reflecting the high status of the water (Dz. U., 2011) in stream types: a siliceous stream at high-altitude in ecoregion $10 \mathrm{MIR} \geq 65$.6; a siliceous stream MIR $\geq 61.8$; a calcareous stream, a flysch stream MIR $\geq 55.4$;

(3) physical and chemical elements (parameters), the values of which reflect the high status of the water: ammonium $\leq 1.4\left(\mathrm{mg} \mathrm{NH}_{4}{ }^{-} 1^{-1}\right)$, phosphates $\leq 0.2$ $\left(\mathrm{mg} \mathrm{PO}_{4}{ }^{3-} \mathrm{l}^{-1}\right)$, nitrites $\leq 0.78\left(\mathrm{mg} \mathrm{NO}_{2}{ }^{-} \mathrm{l}^{-1}\right)$, conductivity $\leq 1,000\left(\mu \mathrm{S} \mathrm{cm}^{-1}\right)$.

\section{Statistical analysis}

Canonical ordination analyses for relating the biological data (the taxonomic composition of benthic macroinvertebrates and the values of metrics) to the environmental variables were carried out using CANOCO for Windows version 4.5 (Ter Braak \& Šmilauer, 2002). The following environmental variables were included into the analysis: the physical and chemical parameters of the water, the total cover of the stream bed by macrophytes, the channel substrate (predominant substrate: bedrock, boulder, cobble, gravel/pebble, sand, silt), the flow type (category: free fall, chute, broken standing waves, unbroken standing waves, chaotic flow, rippled, upwelling, smooth, not visible), values of the HMS, HQA, MIR indices, altitude, and the stream gradient. The appropriate type of analysis (redundancy analysis) was chosen to analyze the biological data using DCA (Detrended Correspondence Analysis) and the length of the gradient. Preliminary DCA on the biological data revealed that the gradient length was less than $3 \mathrm{SD}$ (the standard deviation) indicating that the biological data exhibited linear responses to underlying environmental variables which justified the use of linear multivariate methods. Therefore, a linear direct ordination RDA with a forward selection was used for the reduction of the large set of environmental variables. Taxa that occurred at less than $10 \%$ of the sampling sites were excluded from the statistical analyses following preliminary exploration of their influence in an initial DCA analysis. The statistical significance of the relationship between the biological data and the physical and the environmental variables was evaluated using the Monte Carlo permutation test (499 permutations). Both the biological and environmental data were log-transformed (Ter Braak \& Šmilauer, 2002). The significance of differences in the values of the environmental variables and the values of metrics between stream types was calculated using the Kruskal-Wallis one-way ANOVA test using the Statistica program version 9 . The value of the environmental variables and metrics did not reveal a normal distribution and this justified the use of a non-parametric test.

\section{Results}

The physical and chemical parameters of the waters, the hydromorphological and macrophyte surveys

Siliceous streams at high-altitude (10S-H) are characterized by the low temperature of water, low conductivity (up to $80 \mu \mathrm{S} \mathrm{cm}^{-1}$ ), alkalinity (up to $20 \mathrm{mg} \mathrm{CaCO}_{3} \mathrm{l}^{-1}$ ), $\mathrm{pH}$ (up to 6.7), and concentration of biogenic elements 

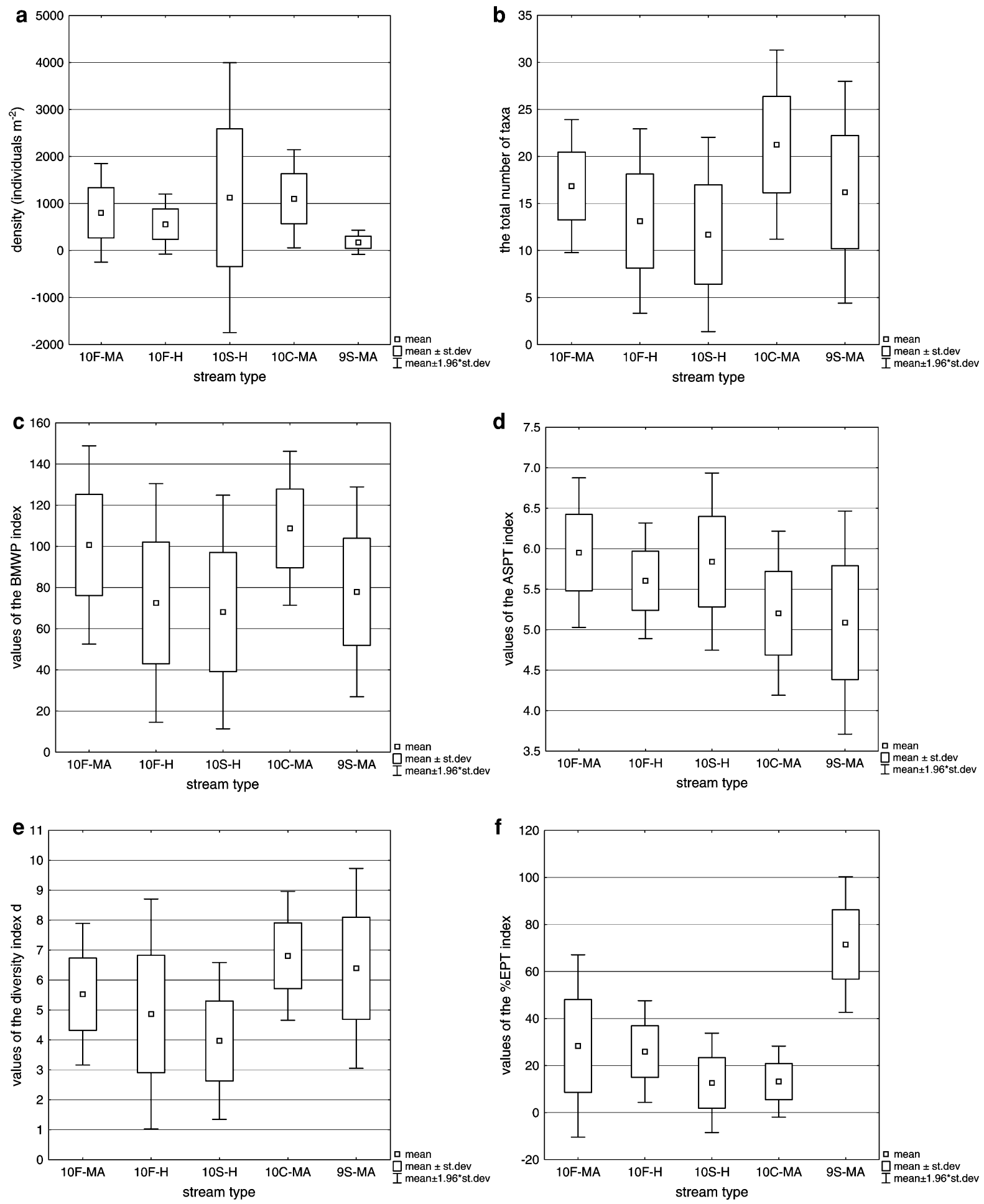

Fig. 2 The values of the biological indices (metrics) of the reference sites in 5 stream types (stream type codes are explained in Table 1). a Density (individuals $\mathrm{m}^{-2}$ ). $\mathbf{b}$ The total

number of taxa. $\mathbf{c}$ The values of the BMWP(PL) index. d The values of the ASPT index. e The values of the diversity index $\mathrm{d}$. f The values of \%EPT index 
Table 2 The values (ranges) of the environmental variables of the reference sites in five stream types

\begin{tabular}{|c|c|c|c|c|c|}
\hline \multirow[t]{2}{*}{ Parameters } & \multicolumn{4}{|l|}{ Ecoregion 10} & \multirow{2}{*}{$\begin{array}{l}\text { Ecoregion } 9 \\
\text { 9S-MA siliceous } \\
\text { (mid-altitude) }\end{array}$} \\
\hline & $\begin{array}{l}\text { 10F-MA flysch } \\
\text { (mid-altitude) }\end{array}$ & $\begin{array}{l}\text { 10F-H flysch } \\
\text { (high-altitude) }\end{array}$ & $\begin{array}{l}\text { 10S-H siliceous } \\
\text { (high-altitude) }\end{array}$ & $\begin{array}{l}\text { 10C-MA calcareous } \\
\text { (mid-altitude) }\end{array}$ & \\
\hline Temperature $\left({ }^{\circ} \mathrm{C}\right)$ & $10.5-17.0$ & $6.4-14.2$ & $6.2-11.1$ & $14.7-18.5$ & $3.9-15.5$ \\
\hline Dissolved oxygen $\left(\mathrm{mg} \mathrm{O}_{2} \mathrm{l}^{-1}\right)$ & $6.2-12.5$ & $5.3-9.6$ & $6.2-9.3$ & $6.1-9.0$ & $7.0-11.2$ \\
\hline Conductivity $\left(\mu \mathrm{S} \mathrm{cm}^{-1}\right)$ & $80-390$ & $60-350$ & $7-80$ & $230-500$ & $17-264$ \\
\hline $\mathrm{pH}$ & $7.2-8.4$ & $6.8-8.1$ & $5.3-6.7$ & $7.7-8.8$ & $6.6-7.6$ \\
\hline Ammonium $\left(\mathrm{mg} \mathrm{NH}_{4}{ }^{-} 1^{-1}\right)$ & $0.02-1.27$ & $0.01-1.41$ & $0.0-0.24$ & $0.05-0.13$ & $0.01-1.32$ \\
\hline Nitrites $\left(\mathrm{mg} \mathrm{NO}_{2}^{-} 1^{-1}\right)$ & $0.0-0.19$ & $0.0-0.19$ & $0.0-0.03$ & $0.01-0.22$ & $0.01-0.16$ \\
\hline Nitrates $\left(\mathrm{mg} \mathrm{NO}_{3}^{-} 1^{-1}\right)$ & $0.44-18.16$ & $0.89-5.76$ & $0.0-0.89$ & $4.87-10.63$ & $1.14-27.47$ \\
\hline Phosphates $\left(\mathrm{mg} \mathrm{PO}_{4}^{3-} 1^{-1}\right)$ & $0.01-0.25$ & $0.01-0.38$ & $0.01-0.07$ & $0.04-0.08$ & $0.01-0.24$ \\
\hline Alkalinity $\left(\mathrm{mg} \mathrm{CaCO}_{3} 1^{-1}\right)$ & $40-140$ & $20-110$ & $5-20$ & $80-205$ & $20-95$ \\
\hline Altitude of sampling sites (m a.s.l.) & $407-774$ & $812-1,217$ & $973-1,729$ & $458-674$ & $209-774$ \\
\hline Stream gradient $(\% 0)$ & $17.1-245.2$ & $109.2-506.0$ & $9.6-550.8$ & $105.0-116.2$ & $5.0-190.0$ \\
\hline HQA index & $49-70$ & $41-76$ & $39-60$ & $66-69$ & $48-62$ \\
\hline Total cover $(\%)$ & $0.2-66.9$ & $1.9-22.4$ & $0.9-46.4$ & $0.1-39.4$ & $2.4-49.1$ \\
\hline MIR index & $57.0-88.6$ & $76.0-85.6$ & $76.1-95.5$ & $78.0-83.8$ & $63.3-93.7$ \\
\hline
\end{tabular}

Table 3 The values (ranges) of the metrics (macroinvertebrates) calculated for the reference sites of five stream types

\begin{tabular}{lccccc}
\hline Metrics & \multicolumn{2}{l}{ Ecoregion 10 } & & Ecoregion 9 \\
\cline { 2 - 5 } & $\begin{array}{l}\text { 10F-MA flysch } \\
\text { (mid-altitude) }\end{array}$ & $\begin{array}{l}\text { 10F-H flysch } \\
\text { (high-altitude) }\end{array}$ & $\begin{array}{l}\text { 10S-H siliceous } \\
\text { (high-altitude) }\end{array}$ & $\begin{array}{l}\text { 10C-MA calcareous } \\
\text { (mid-altitude) }\end{array}$ & $\begin{array}{l}\text { 9S-MA siliceous } \\
\text { (mid-altitude) }\end{array}$ \\
\hline Density (individuals m ${ }^{-2}$ ) & $111-2,189$ & $267-1,322$ & $316-5,224$ & $401-1,673$ & $22-329$ \\
The total number of taxa & $10-24$ & $5-20$ & $6-24$ & $14-26$ & $6-26$ \\
BMWP(PL) & $59-141$ & $28-122$ & $32-122$ & $82-123$ & $35-113$ \\
ASPT & $4.43-6.63$ & $4.91-6.10$ & $5.30-6.85$ & $4.69-5.86$ & $3.52-5.83$ \\
The diversity index d & $3.38-7.99$ & $1.88-8.12$ & $2.06-6.45$ & $5.38-7.72$ & $3.79-9.0$ \\
\%EPT & $6.28-76.04$ & $8.90-45.69$ & $1.81-39.61$ & $5.69-20.67$ & $41.0-88.0$ \\
\hline
\end{tabular}

compared to the other stream types (Table 2). Low values of the biogenic elements were recorded at the reference sites of siliceous streams at high-altitude (10S-H). Higher values of temperature (up to $18.5^{\circ} \mathrm{C}$ ), $\mathrm{pH}$ (up to 8.8), conductivity (up to $500 \mu \mathrm{S} \mathrm{cm}^{-1}$ ), and alkalinity (up to $205 \mathrm{mg} \mathrm{CaCO}_{3} \mathrm{l}^{-1}$ ) were recorded in calcareous streams at mid-altitude (10C-MA) (Table 2). The concentration of nitrates was the highest in the siliceous streams at mid-altitude (9S-MA) compared to the other stream types. The altitude of the reference sampling sites ranged from 209 to $1,729 \mathrm{~m}$ a.s.l., whereas the stream gradient ranged from 5.0 to $550.8 \%$ (Table 2).

The total cover of the stream bed by macrophytes ranged from $0.1 \%$ in a calcareous stream at midaltitude (10C-MA) to $66.9 \%$ in a flysch stream at mid- altitude (10F-MA). The highest maximum value of the MIR index (95.5) was recorded in siliceous streams at high-altitude (10S-H) (Table 2). The values of the HQA index ranged from 41 to 76 , however, lower values were recorded at a few sampling sites in both flysch and siliceous streams at high-altitude situated above 1,200 $\mathrm{m}$ a.s.l.

The Kruskal-Wallis one-way ANOVA test revealed statistically significant differences in the values of the physical and chemical parameters of water, e.g., temperature $(H=27.57, P=0.0001)$, conductivity $(H=$ $35.54, P=0.0001), \mathrm{pH}(H=38.22, P=0.0001)$, ammonium $(H=27.27, P=0.0001)$, nitrites $(H=$ $17.33, P=0.002)$, nitrates $(H=24.87, P=0.0001)$, phosphates $(H=16.85, P=0.002)$, alkalinity $(H=$ $34.11, P=0.0001)$ as well as altitude $(H=38.40$, 


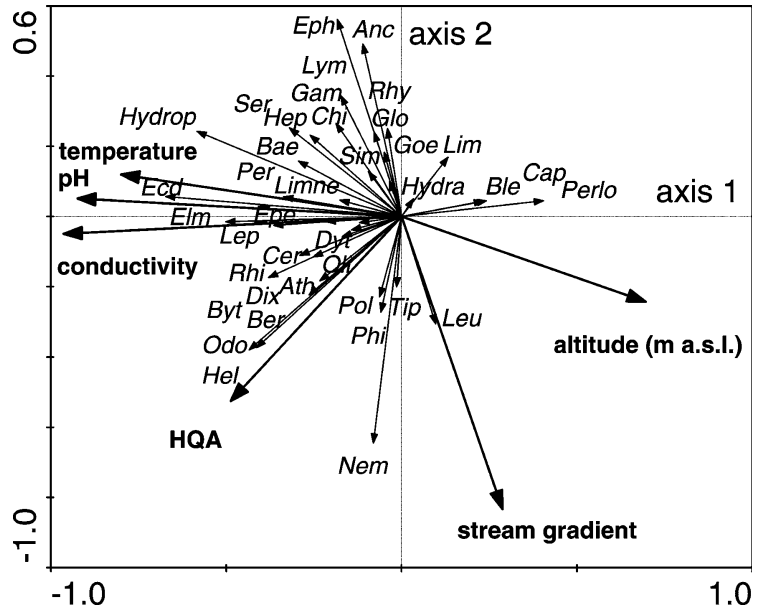

Fig. 3 Ordination diagram (biplot) based on a redundancy analysis (RDA) of benthic macroinvertebrates and selected environmental variables. The long arrows representing some environmental variables emphasize their great impact on the benthic macroinvertebrate distribution. Anc Ancylidae, Ath Athericidae, Bae Baetidae, Ber Beraeidae, Ble Blephariceridae, Byt Bythinella (Hydrobiidae), Cap Capniidae, Cer Ceratopogonidae, Chi Chironomidae, Dix Dixidae, Dyt Dytiscidae, Ecd Ecdyonurus, Elm Elmidae, Epe Epeorus, Eph Ephemerellidae, Gam Gammaridae, Glo Glossosomatidae, Goe Goeridae, Hel Helodidae, Hep Heptagenia, Hydra Hydracarina, Hydrop Hydropsychidae, Leu Leuctridae, Lep Leptophlebiidae, Limne Limnephilidae, Lim Limoniidae, Lym Lymnaeidae, Nem Nemouridae, Odo Odontoceridae, Oli Oligochaeta, Per Perlidae, Perlo Perlodidae, Phi Philopotamidae, Pol Polycentropodidae, Rhi Rhitrogena, Rhy Rhyacophilidae, Ser Sericostomatidae, Sim Simuliidae, Tip Tipulidae

$P=0.0001)$, the stream gradient $(H=14.96, P=$ $0.005)$, the HQA index $(H=15.28, P=0.004)$ and the MIR index $(H=13.33, P=0.01)$ with the exception of the dissolved oxygen $(H=8.01, P=0.09)$ and the total cover of macrophytes in the stream bed $(H=2.82$, $P=0.59$ ) between stream types.

Macroinvertebrate families scoring and the values of the metrics

In total, 66 macroinvertebrate taxa were recorded at the reference sampling sites. The number of taxa ranged from 5 in the flysch stream at high-altitude $(10 \mathrm{~F}-\mathrm{H})$ to 26 in both the calcareous and siliceous streams at mid-altitude (10C-MA and 9S-MA), whereas the density ranged from 22 (siliceous streams at mid-altitude 9S-MA) to 5,224 individuals $\mathrm{m}^{-2}$ (siliceous streams at high-altitude 10S-MA) (Table 3).

The highest mean density $(1,124.50 \pm 146.50$ individuals $\mathrm{m}^{-2}$ ) was observed in siliceous streams

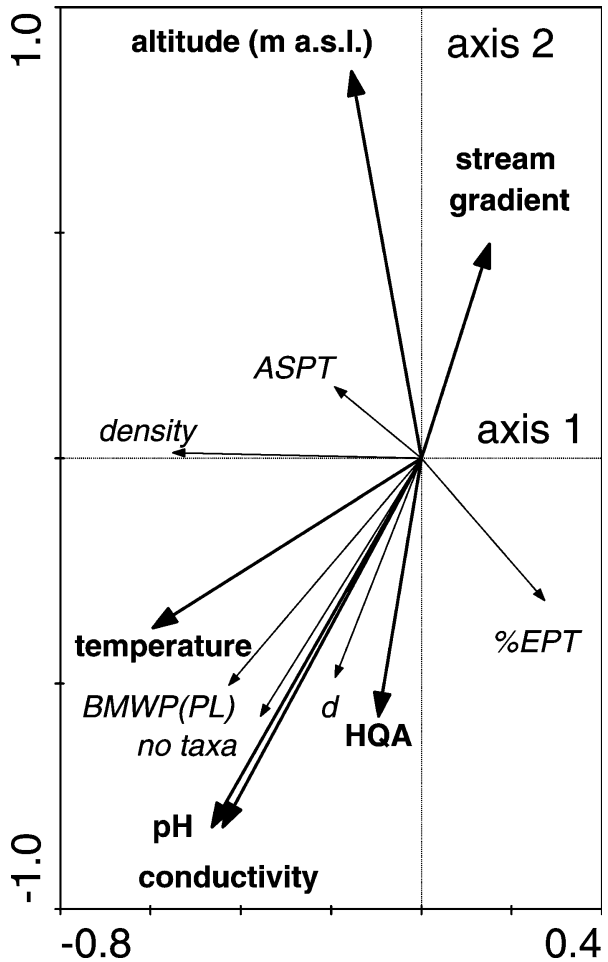

Fig. 4 Ordination diagram (biplot) based on a redundancy analysis (RDA) of the biological indices (metrics) and selected environmental variables. No taxa the total number of taxa, $\mathrm{d}$ the values of the diversity index $d$

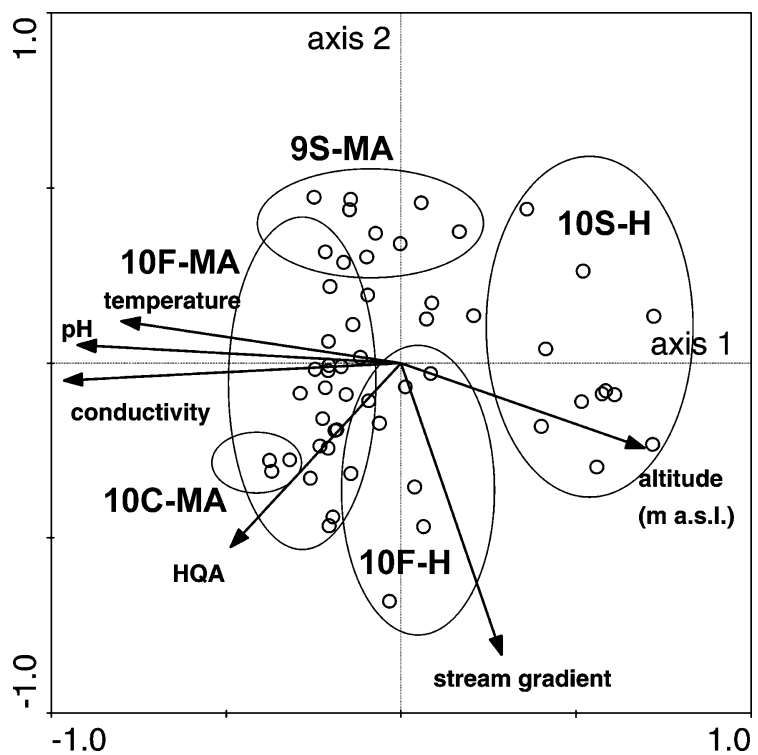

Fig. 5 Ordination diagram (biplot) based on a redundancy analysis (RDA) of the reference sites in relation to the selected environmental variables 
at high-altitude $(10 \mathrm{~S}-\mathrm{H})$, whereas the highest mean the total number of taxa was observed in a calcareous stream at mid-altitude (10C-MA) (Fig. 2a, b).

Larvae of the dipteran family Blephariceridae (10 points on a scale from 1 to 10 according to the BMWP(PL) methodology) were observed at 7 out of the 58 sampling sites (mainly in siliceous and flysch streams at high-altitude (10S-H, 10F-H) located in the Tatra National Park and the Babia Góra National Park), whereas Thaumaleidae (10 points on a scale from 1 to 10 according to the BMWP(PL) methodology) were found only at 2 sites (10F-H and 10C-MA). Larvae of the trichopteran family Odontoceridae (10 points on a scale from 1 to 10 according to the BMWP(PL) were recorded at 19 out of 58 reference sites, mainly in flysch streams at mid-altitude (10F-MA), the Gorce National Park. Goeridae and Lepidostomatidae (9 points) were recorded at 14 sites in flysch streams at mid- and highaltitude (10F-MA, 10F-H) and in siliceous streams at mid-altitude (9S-MA). Limnephilidae (7 points) was observed at 49 sites. The maximum value of the BMWP(PL) metric, e.g., 141, was recorded in a flysch stream at mid-altitude (19F-MA). Wide ranges of the diversity index $d$ were recorded in flysch streams at high-altitude (10F-H) and siliceous streams at midaltitude (9S-MA) (Table 3).

The mean value of the BMWP(PL) index ranged from $68.10 \pm 28.96$ in siliceous streams at highaltitude (10S-H) to $108.75 \pm 19.10$ in calcareous stream at mid-altitude (10C-MA) (Fig. 2c). The highest mean value of the ASPT index $(5.95 \pm 0.47)$ was calculated in flysch streams at mid-altitude (10FMA), whereas, the highest mean of the diversity index $\mathrm{d}(6.81 \pm 1.10)$ was recorded in calcareous streams at mid-altitude (10C-MA) (Fig. 2d, e). The mean value of the \%EPT index calculated for siliceous streams at mid-altitude in ecoregion 9 was considerably high compared to the mean values of \%EPT in all types of streams in ecoregion 10 (Fig. 2f). The lowest number of taxa, values of the BMWP(PL) or diversity indices $d$ were recorded at reference sites of siliceous streams situated above $1,500 \mathrm{~m}$ a.s.l., e.g., in the Tatra National Park and flysch streams above 1,200 m a.s.l.

The values of BMWP(PL) above 100 and the diversity index $\mathrm{d}$ above 5.5 , which indicate a very good quality of water were recorded at 17 out of the 58 sampling sites excluding sites situated above $1,200 \mathrm{~m}$ a.s.l. The following families: Dixidae, Tabanidae, Isotomidae, Hydraenidae, and Helodidae were recorded at the sampling sites. However, they are not included into the BMWP(PL) methodology. According to Glöer (2002), the gastropod species Ancylus fluviatilis O. F. Müller, 1774 belongs to the family Planorbidae (4 points in the BMWP(PL) methodology), not Ancylidae (3 points). Thus, small inconsistencies exist between the systematics and BMWP(PL) methodology.

Higher values of \%EPT above $50 \%$, which indicate good water quality, were recorded at only 15 out of the 58 sampling sites in siliceous streams mainly at midaltitude (9S-MA).

The Kruskal-Wallis one-way ANOVA test revealed statistically significant differences in the mean values of all metrics: macroinvertebrate density $(H=23.79$, $P=0.0001)$, the total number of taxa $(H=13.83$, $P=0.008)$, BMWP(PL) $(H=14.33, P=0.006)$, ASPT $(H=18.71, P=0.0009)$, the diversity index $\mathrm{d}(H=14.93, P=0.005)$, and \%EPT $(H=29.11$, $P=0.0001)$ between stream types.

Redundancy analysis (RDA)

RDA analysis based on the biological data and environmental variables showed that the first two axes explain $23.3 \%$ of the variance of biological data and $63.2 \%$ of the variance of biological data and environment relations. Conductivity, stream gradient, altitude, value of the HQA index, temperature of the water and $\mathrm{pH}$ were the parameters most associated (statistically significant according to the forward selection results) with the distribution of benthic macroinvertebrate taxa and values of the metrics. Three different patterns of the distribution of benthic macroinvertebrates were found: (1) Hydropsychidae, Perlidae, Ecdyonurus, Heptagenia, and Leptophlebiidae were the taxa situated close to the arrow indicating $\mathrm{pH}$, conductivity, temperature, whereas Perlodidae, Blephariceridae, and Capniidae were situated on the opposite side close to the arrow indicating altitude, (2) Leuctridae was the taxa situated close to the arrow indicating the stream gradient, and Ephemerellidae, Ancylidae, Rhyacophilidae, and Chironomidae were situated on the opposite side, and (3) Helodidae, Odontoceridae, Rhitrogena, Dixidae, Athericidae, Nemouridae, Beraeidae, Philopotamidae, and Bythinella Moquin-Tandon, 1856 were the taxa correlated with the higher values of the HQA index (Fig. 3). The relation between the taxonomic composition of benthic macroinvertebrate taxa and the environmental variables was statistically significant 
(test of significance of first canonical axis: $P=0.002$, $F$ ratio $=4.097$, test of significance of all canonical axes: $P=0.002, F$ ratio $=2.174)$.

The values of the BMWP(PL), the diversity index $d$ and the total number of taxa were positively correlated with conductivity, $\mathrm{pH}$, temperature, and values of the HQA index but were negatively correlated with the stream gradient (Fig. 4). Moreover, the values of BMWP(PL) or diversity index $d$ showed a positive correlation with the total number of taxa. The values of the \%EPT index were negatively correlated with altitude.

Angles between the arrows of the metrics or benthic macroinvertebrate taxa and selected environmental variables in an ordination diagram from linear methods show a positive (acute angle) or a negative (straight angle) correlation.

The relation between the values of metrics, the taxonomic composition of benthic macroinvertebrate taxa and the environmental variables was statistically significant (test of significance of first canonical axis: $P=0.01, F$ ratio $=14.998$, test of significance of all canonical axes: $P=0.004, F$ ratio $=3.390)$.

Figure 5 shows the reference sites in relation to the selected environmental variables. On the ordination diagram, the reference sites of siliceous streams at high-altitude (10S-H) are grouped closer on the opposite side of the arrow indicating $\mathrm{pH}$, conductivity, and temperature (low values of $\mathrm{pH}$, conductivity, temperature). The reference sites of calcareous and flysch streams at mid-altitude (10C-MA, 10F-MA) are grouped closer to the arrow indicating $\mathrm{pH}$, conductivity, and temperature as well as values of the HQA index (higher values of these environmental variables). The reference sites at high-altitude are grouped closer to the arrow indicating altitude (siliceous streams 10S-H) or the stream gradient (flysch streams 10F-H), while sites at mid-altitude (flysch streams 10F-MA, siliceous streams 9S-MA) are grouped on the opposite side.

\section{Discussion}

The values of metrics

within and among ecoregions

According to Birk \& Hering (2006), in ecoregions 9 and 10, which include small siliceous mountain streams of the Slovak Republic, the Czech Republic and Poland, the reference value for ASPT $\geq 6.62$. Our survey showed only one reference site for ASPT $\geq 6.62$ (10S-H, the Slovak Republic) within the same category, e.g., the small siliceous mountain stream in ecoregion 10. The values of ASPT in other reference sites of siliceous streams were lower and ranged from 5.30 to 6.54 in high-altitude streams (10S-H), but from 3.52 to 5.83 in mid-altitude streams (9S-MA).

We obtained the minimum and maximum values of the BMWP(PL) and ASPT indices from 28 (flysch stream at high-altitude $10 \mathrm{~F}-\mathrm{H}$ ) to 141 (flysch stream at mid-altitude 10F-MA, the Gorce National Park) and from 3.52 (siliceous stream at mid-altitude 9S-MA) to 6.85 (siliceous stream at high-altitude $10 \mathrm{~S}-\mathrm{H}$, the Tatra National Park), respectively. In comparison, in the river reference sampling sites of the Berezina Biospheric Reserve, the values of BMWP and ASPT ranged from above 50-130 and above 4-6 (Semenchenko \& Moroz, 2005). Our survey showed the mean values of BMWP(PL) ranged from 68.10 to 108.75, the mean values of ASPT from 5.09 to 5.95 and the number of families up to 66 in the reference (unimpacted) sites of ecoregions 9 and 10. In contrast, much lower mean values of the BMWP(PL) index from 55.5 to 60.8 were obtained by Królak \& Korycińska (2008) for impacted rivers within ecoregion 16 (Eastern Plains) in Poland. They also recorded that the values of diversity index $d$ ranged from 0.56 to 10.58. At reference sites, we obtained similar ranges of the values of the diversity index $\mathrm{d}$ from 1.88 to 9.0. In impacted rivers within ecoregion 14 (Central Plains), mean values of BMWP(PL) and ASPT indices ranged from 30 to 140 and from 3 to above 5, respectively (Bis et al., 2000). Within the same region, the values of the BMWP(PL) ranged from 27 to 93, and only 44 benthic macroinvertebrate families occurred at impacted river sampling sites (Czerniawska-Kusza, 2005). The values of the IBMWP $>100$ and IASPT $>5.5$, for example, were established in reference sites for Pyrenean rivers (Leunda et al., 2009).

These results showed a mean value of the ASPT index of 5.95 in reference sites in flysch streams at midaltitude, ecoregion 10, e.g., the Carpathians (10F-MA). Considering the same stream type and ecoregion, Wyżga et al. (in press) obtained mean values of the ASPT and BMWP(PL) indices for unmanaged and channelized sampling sites. The mean values of the ASPT index were higher, but similar both for unmanaged and channelized sampling sites and amounted to 6.70 and 6.75 , respectively. The value of the 
BMWP(PL) index for unmanaged sites varied from 59 to 125 (mean 84), whereas for channelized sites from 18 to 72 (mean 35). In contrast, our results showed a higher mean of the BMWP(PL) index (100.69 \pm 24.58 ) and a higher maximum value (up to 141).

Values of metrics in relation to geology, the physical and chemical parameters of water and altitude

Our study revealed statistically significant differences in the mean values of macroinvertebrate density as well as \%EPT in sampling sites among all stream types. In addition, the ranges of \%EPT were relatively wide depending on the stream types. In contrast, Medhurst et al. (2010) found a lack of statistically significant differences among \%EPT in headwater streams within 4 ecoregions at mean elevations of $798-1,095 \mathrm{~m}$ a.s.l. which varied from 36.4 to 44.5 only. It was proved (Jacobsen et al., 2003) that the values of ASPT and \%EPT indices decrease with an increase in altitude. According to Jacobsen et al. (2003), the values ranged from 6.04 to 6.86 (ASPT) and from 21 to 53 (\%EPT) at altitudes of 100-600 m a.s.l., while above $600 \mathrm{~m}$ the values of metrics decreased. Our results confirmed their survey, because the values of \%EPT decreased with an increase in altitude.

This survey found statistically significant differences in the mean values of all metrics including macroinvertebrate density and the total number of taxa among the stream types of the two ecoregions. This result is consistent with Sandin \& Johnson (2000b), who showed that in the reference conditions, including streams up to an elevation of $800 \mathrm{~m}$, the number of macroinvertebrate taxa, density, and diversity differed among ecoregions. In Sweden, for example, they recorded a lower number of taxa, density, and biological indices in regions with the lowest mean annual temperature and high altitudes. Altitude, geology, and the temperature of the water are important factors that explain variability in macroinvertebrate structures among streams in ecoregions (Sandin \& Johnson, 2000b; Gibbins et al., 2001; Bona et al., 2008; Tripole et al., 2008; Péru \& Dolédec, 2010). Our survey is consistent with their results, but contrast with the survey of Verdonschot (2006) in which he showed that the number of taxa in reference sites in many European streams was neither correlated with altitude nor with the temperature of the water. However, Kroll et al. (2009) pointed out that the influence of land use on water quality and macroinvertebrate structure was more important than geology. For example, Harding et al. (1998) showed a decline in the total number of macroinvertebrate taxa, values of the EPT, and diversity indices in human-impacted streams in comparison to forested streams. Considering land use within $50 \mathrm{~m}$ of bank top, our survey showed forested streams: coniferous or mixed woodlands.

Very low values of the BMWP(PL), diversity indices $\mathrm{d}$ and the total number of taxa were recorded in siliceous streams at high-altitude (10F-H) (the Tatra National Park, Poland and the Slovak Republic) and also in flysch streams within the Biosphere Reserve (10F-H). The altitude of these sampling sites ranged from 1,200 to $1,729 \mathrm{~m}$ a.s.l. Low values of metrics may indicate very poor water quality and probably do not reflect the real ecological status of these streams. The absence of any obvious sources of pollution and the pristine nature of these streams, as proved by the physical and chemical parameters of water or values of the HQA index may suggest other reasons for the low metric values. Thus, this phenomenon could be explained by harsh extreme conditions, high altitude, low temperatures, conductivity, $\mathrm{pH}$ or alkalinity, and also by geology. For example, we recorded extremely low $\mathrm{pH}$ (from 5.3 to 5.7) in streams situated above $1,700 \mathrm{~m}$ in the granite High Tatra Mts $(10 \mathrm{~F}-\mathrm{H})$. This result is consistent with the survey by Tripole et al. (2008), which showed a decrease in the total number of taxa (up to 34 taxa) at an elevation of $1,690 \mathrm{~m}$ and $\mathrm{pH}$ 3.6-5.5, especially in ephemeropteran and trichopteran larvae. They recorded an increase in the total number of taxa (up to 65 taxa) with a decrease in elevation from 1,660 to $1,550 \mathrm{~m}$ and $\mathrm{pH}$ ranging from 6.7 to 9.5 . In natural or near-natural siliceous streams situated 1,200-1,900 m a.s.l. (the Gran Paradiso National Park, Italy), the value of BMWP and ASPT ranged 50-115 and 6.50-7.29, respectively (Bona et al., 2008). Low values of the BMWP index were recorded at 9 out of the 12 sampling sites. Thus, Bona et al. (2008) regarded the EPT index as the most appropriate for application in high-altitude streams in comparison to the BMWP. At similar altitudes and channel geology (siliceous streams), the values of BMWP(PL) or ASPT were much lower amounting up to 89 and up to 6.85 (the High Tatra, the Tatra National Park, Poland, the Tatranský Národný Park). Our 
results showed that neither the BMWP(PL) index nor the \%EPT index is appropriate for application in sampling sites situated above 1,200 m a.s.l.

It was proved that with a minimum decrease in oxygen saturation, the proportion of EPT taxa in the total macroinvertebrate fauna is lower and decreases faster in high-mountain streams in comparison to lowland streams (300-600 m a.s.l.) (Jacobsen et al., 2003). Taxonomic richness, diversity, and the number of taxa, especially Ephemeroptera, Plecoptera, Trichoptera, or Coleoptera, increase downstream in highmountain streams (Miserendino \& Pizzolón, 2000; Maiolini \& Lencioni, 2001). Thus, low values of BMWP(PL) or \%EPT indices may be explained by a low proportion of EPT taxa in the total macroinvertebrates at the reference sites in both siliceous (10S-H) and flysch (10F-H) streams at high-altitude. In contrast, Casado et al. (2001) found 88 families and IBMWP values between 110 and 201 in headwater mountain streams of a protected area situated within 905-1,810 $\mathrm{m}$ a.s.l. with a $\mathrm{pH}$ ranging from 6.6 to 7.5.

These surveys revealed that $\mathrm{pH}$, conductivity, and water temperature were statistically significant parameters that influenced the distribution of benthic macroinvertebrate taxa and the values of metrics. This result confirmed the survey of Gibbins et al. (2001) that the variation in invertebrate community structure was most strongly correlated with water temperature and $\mathrm{pH}$ as well as conductivity. Sandin (2003) also highlighted $\mathrm{pH}$ as an important variable associated with the community structure of benthic macroinvertebrates in streams of different ecoregions. A low $\mathrm{pH}$ adversely affects the community structure of benthic macroinvertebrates in numerous headwater mountain streams including the values of EPT richness (Baldigo et al., 2009). A low $\mathrm{pH}$ of headwater mountain streams may be explained by the type of substratum and geology (Gibbins et al., 2001). For example, granitic rock types give rise to acidic soils, and often develop on glacial drifts and periglacial deposits. Gibbins et al. (2001) obtained significant differences in the number of taxa and density between streams on granite and on schist situated at altitudes from 280 to $1,118 \mathrm{~m}$ a.s.l. The mean number of taxa and density ranged from 15 to 23 and 197 to 834 individuals $\mathrm{m}^{-2}$ (granite) or 23-27 and 259-606 individuals $\mathrm{m}^{-2}$ (schist), respectively. Our survey showed a similar tendency, e.g., streams on granite have fewer taxa than others but only in the case of sampling sites situated above 1,500 m a.s.l. in the High Tatra Mts. (10S-H). We also recorded a lower density of macroinvertebrates in streams on schist $(10 \mathrm{~F}-\mathrm{H})$. Our result is in contrast to that of Rawer-Jost et al. (2004), who concluded that in the stream types of lower mountain regions, a separation of siliceous and calcareous types does not seem to be crucial for bioassessment at the metric level. We obtained statistically significant differences in the values of all metrics depending on the siliceous (10S-H, 9S-MA) or calcareous (regions 10C-MA) type of streams below $800 \mathrm{~m}$ a.s.l. and above.

The relationships among the physical and chemical parameters of water, altitude, and the distribution of benthic macroinvertebrates

Results of the RDA ordinations suggested that water temperature, $\mathrm{pH}$, conductivity, and altitude were the parameters most associated (statistically significant) with the distribution of benthic macroinvertebrate taxa. The densities of the same taxa, e.g., Perlidae, Ecdyonurus, Baetidae, Hydropsychidae, Heptagenia, and Leptophlebiidae were correlated with a higher value of $\mathrm{pH}$. Baldigo et al. (2009) stated that low $\mathrm{pH}$ adversely affects the benthic macroinvertebrate community structure in numerous headwater streams of the western Adirondack Mountains and certain acidsensitive species are replaced by more tolerant species. Adirondack Mountain streams with a $\mathrm{pH}<5.5$ were dominated by stoneflies (Leuctra, Isoperla) and blackflies Simuliidae. According to his survey, Rhyacophila, Epeorus, Leuctra belong to the acidophilus macroinvertebrate genera. Clarke and Scruton (1997) also showed e.g., that Heptagenia and Gastropoda were absent from streams below $\mathrm{pH} 6.1$. Similarly, in our survey, both Heptagenia and Gastropoda were absent from the siliceous streams with the lowest values of $\mathrm{pH}$ at high-altitude (10F-H, High Tatra Mts.), but were recorded in calcareous streams at mid-altitude (10C-MA, the Pieniny Mts.). Low pH is probably not the only factor responsible for the impoverishment of benthic macroinvertebrates. Food resources are less available in acidic streams. Other important factors, such as the low amount of food and low food quality, insufficient concentration of essential dissolved components, e.g., calcium content (Sandin, 2003) may also be considered. 
Many authors consider altitude and water temperature to be major factors in determining the community structure of macroinvertebrates in mountain streams (Miserendino \& Pizzolón, 2000; Miserendino, 2001; Jacobsen \& Marín, 2008). According to Miserendino \& Pizzolón (2000), dipteran larvae Blephariceridae were most abundant at an elevation of 1,350 m. a.s.l. Our survey confirmed their results. We recorded Blephariceridae at reference sites at higher altitudes with a lower water temperature. In our survey, plecopteran larvae Capniidae or Perlodidae showed a similar distribution pattern as Blephariceridae. Environmental variables, i.e., altitude, water temperature, or dissolved oxygen depend on each other and it is impossible to consider them separately. Water temperature has an influence on metabolism, growth, feeding rates, fecundity, or the survival behavior of macroinvertebrates. Plecoptera, Trichoptera, and Ephemeroptera, including species within the family Heptageniidae, belong to the group that is highly thermally sensitive. For example, the upper thermal limit of the Notonemouridae amounted to $23.0^{\circ} \mathrm{C}$, whereas for species within Heptageniidae, it ranged from 11.7 to $25.5^{\circ} \mathrm{C}$ (Dallas \& Ketley, 2011). Species within Blephariceridae belong to the cold-stenotherm. Their occurrence is restricted to the streams at higher altitudes with low temperatures. In such streams, temperatures in spring and early summer are cool long enough to enable larval and pupal development (Frutiger \& Meier Buergisser, 2002). Thus, in our survey, positive correlations between altitude (water temperature) and distribution of Blephariceridae or other taxa may be explained by their physiological make up. The crucial role of water temperature as a major variable in explaining the gradient in benthic macroinvertebrate community structures in mountain streams at altitudes up to $1,550 \mathrm{~m}$ a.s.l. as well as in streams located in the lower mountainous area of Central Europe (Haidekker \& Hering, 2008) was also confirmed by Brittain et al. (2001).

Values of metrics and the benthic macroinvertebrate distribution in relation to hydromorphology

According to Wyżga et al. (2012) and Wyżga et al. (in press), the total number of macroinvertebrate taxa and the values of the BMWP(PL) index were not correlated with the physical and chemical parameters of the water, which consistently reflect its high quality in the mountain streams of the Carpathians. The physical habitat in streams, which includes velocity, type of substratum, and substrate grain size or water depth, seems to be the best predictor in the distribution of benthic macroinvertebrates. They obtained a statistically significant correlation between the total number of taxa, the values of the BMWP(PL) and the number of flow threads as well as a cross-sectional variation of depth-average velocity.

This survey found that of a variety of environmental factors including the physical and chemical parameters of water which reflected geology, the total cover of the stream bed by macrophytes, the channel substrate, the flow type, values of the Habitat Modification Score (HMS), and Habitat Quality Assessment (HQA) indices, the most important (statistically significant) factors that explained the distribution of macroinvertebrates also included the stream gradient and the values of the HQA index. The values of the HQA and HMS indices permit the reference sites to be separated from the disturbed ones (Cortes et al., 2008). The HQA is a broad indication of the overall habitat diversity provided by the natural features in the channel and river corridor. The HQA index incorporates a variety of measures of habitat quality including flow types, channel substrates, and deposition features, in-channel vegetation, and also the distribution of bank-side trees and the extent of near natural land-use adjacent to the river. In contrast to HMS, higher HQA scores represent more diverse sites. The character and pattern of features in a sampling site are influenced by natural variation and also by the extent of human intervention both in the channel and on the adjacent land. The HMS is an indication of artificial modification to the river channel morphology (Szoszkiewicz et al., 2006; Raven et al., 2011). The values of the HQA index, calculated for streams in most European ecoregions, varied between 10 and 80 points (Szoszkiewicz et al., 2006). Streams with a higher value of the HQA index show a high degree of naturalness. This survey obtained values of the HQA index ranging from 39 to 76 . However, lower values were recorded in a few sampling sites both in flysch streams at high-altitude situated above $1,200 \mathrm{~m}$ a.s.l. in the Babia Gora Massif and in a siliceous streams above 1,500 m a.s.l. in the High Tatra Mts. Lower values of the HQA index are typical for streams situated in the alpine and subalpine zones. There are a distinct vegetation zones that are dependent 
on the habitat and climatic conditions in both in the Babia Góra Massif and in the Tatra Mts. Climatic conditions are extreme there. Snow cover on the highest peaks can last for 200 days a year, with some snowfields present all year. The pine dwarf (Pinus mugo) occurs above the tree line, between about 1,500-1,800 $\mathrm{m}$ a.s.l. in the Tatra Mts., but from about 1,200 m a.s.l. in the Babia Gora Massif. The value of the HQA index also includes the distribution of bankside forests and the extent of near-natural land-use adjacent to the streams, whereas in the alpine zone, the pine dwarf rather than forests is predominant and the landscape is largely rock and scree. Thus, lower values of the HQA index of streams situated above the tree line are not the result of their degradation but this phenomenon may be explained by the natural hydromorphological and harsh climatic made-up.

Our findings showed an increase in the values of the BMWP(PL), d indices, the total number of taxa as well as the density of some macroinvertebrate taxa with a high score according to the BMWP(PL) methodology with an increase in the degree of the naturalness of the streams. The more vulnerable the macroinvertabrates are, the higher the score of taxa. These taxa include Odontoceridae, Beraeidae, Philopotamidae, Athericidae, Dixidae, and Rhitrogena as well as the gastropod Bythinella (Hydrobiidae). In Poland, all gastropod species within the genus Bythinella are recorded in the Red List of species as near threatened (NT) or vulnerable (VU) (Piechocki, 2002).

\section{Conclusions}

Our results showed the crucial role of water temperature, $\mathrm{pH}$, conductivity, the stream gradient, values of the HQA index, and altitude as major variables in explaining the gradient in benthic macroinvertebrate distribution at reference conditions in the high- and mid-altitude mountain streams of two ecoregions 9 and 10. The diversification of these parameters is strongly related to the river typology. Therefore, the importance of the river type approach for any invertebrate-based assessment was confirmed. The ranges of metric values were established in relation to the environmental variables based on benthic macroinvertebrates.

These surveys revealed that at the reference conditions the suggested border values of biological indices are very harsh. The values of the biological indices (metrics) of most sampling sites did not correspond to the requirements of the high status in rivers and should be verified according to the necessity of highland and mountain streams monitoring. Values of the BMWP(PL) index above 100 and the diversity index $\mathrm{d}$ above 5.5, which confirmed very good quality of water, were recorded only at a few sampling sites, mainly for midaltitude mountain streams. The macroinvertebrate metrics did not confirm the ecological status of rivers at high altitudes. Very low values of the BMWP(PL), diversity indices $\mathrm{d}$ and the total number of taxa recorded at sampling sites situated above 1,200 $\mathrm{m}$ a.s.l. within protected areas (e.g., the Biosphere Reserve, the Babia Góra National Park, and the Tatra National Park) indicated the very poor water quality of the pristine streams. The indices which were confirmed in lowland and highland rivers did not work well in the harsh extreme conditions, high altitude, low water temperature, conductivity, $\mathrm{pH}$ or alkalinity, and geology. The streams at altitudes above $1,200 \mathrm{~m}$ a.s.l. should be treated as another river type and new reference values as well as border values should be established for the 5 classes of ecological quality for the classification requirements.

Acknowledgments The authors are deeply indebted to the anonymous reviewers for their valuable suggestions and comments on this manuscript. This research was supported by the Ministry of Science and Higher Education (contract no $39 / 2007 / \mathrm{GW}$ ). The authors are very grateful to the Director Agnieszka Dalbiak and the Head of Department Wojciech Hurkała, Ministry of the Environment, Department of Nature Conservation; Director mgr inż. Józef Omylak, the Babia Góra National Park; Director mgr inż. Janusz Tomasiewicz, the Gorce National Park; Director mgr inż. Michał Sokołowski and mgr Krzysztof Karwowski, the Pieniny National Park; mgr Jolanta Prażuch, Regionalna Dyrekcja Ochrony Środowiska in Katowice; Ministerstvo životného prostredia Slovenskej republiky, Tatranský Národný Park, the Slovak Republic for the cooperation and permission to carry out the field survey within national parks and the nature reserve "Wisła". The authors gratefully acknowledge the field cooperation of Dr. Francis Hugh Dawson, NERC, Centre for Ecology and Hydrology, Wallingford, UK; Dr. Paul Raven, Head of Conservation and Ecology, Environment Agency, Bristol, UK; Dr. Nigel Holmes, Alconbury Environmental ConsultantsEnvironment Agency external technical adviser for conservation, UK; Dr. Eva Bulánková, Department of Ecology, Faculty of Natural Sciences, Comenius University in Bratislava for her cooperation and expert guidance within the Tatranský Národný Park, the Slovak Republic; Zbigniew Rymarski, Ph.D., D.Sc.(Eng.), Silesian University of Technology in Gliwice for help in the initial field recognition and help in computer graphics; Tomasz Zgoła, Ph.D.(Eng.) and Marta Szwabińska, M.Sc.(Eng.), Poznań University of Life 
Sciences for field and laboratory work cooperation. We are also grateful to Ms. Michele L. Simmons, B.A., English Language Centre (ELC), University of Silesia, Katowice, Poland for improving the English style.

Open Access This article is distributed under the terms of the Creative Commons Attribution License which permits any use, distribution, and reproduction in any medium, provided the original author(s) and the source are credited.

\section{References}

Aqem, 2002. Manual for the Application of the Aqem System. A Comprehensive Method to Assess European Streams Using Benthic Macroinvertebrates, Developed for the Purpose of the Water Framework Directive. Version 1.0, February 2002. www.aqem.de.

Baattrup-Pedersen, A., E. A. Kristensen, J. Jørsen, J. Skriver, B. Kronvang, H. E. Andersen, C. C. Hoffman \& L. M. K. Larsen, 2009. Can a priori defined reference criteria be used to select reference sites in Danish streams? Implications for implementing the Water Framework Directive. Journal of Environmental Monitoring 11: 344-352.

Baldigo, B. P., G. B. Lawrenc, R. W. Bode, H. A. Simonin, K. M. Roy \& A. J. Smith, 2009. Impacts of acidification on macroinvertebrate communities in streams of the western Adirondack Mountains, New York, USA. Ecological Indicators 9: 226-239.

Birk, S. \& D. Hering, 2006. Direct comparison of assessment methods using benthic macroinvertebrates: a contribution to the EU Water Framework Directive intercalibration exercise. Hydrobiologia 566: 401-415.

Bis, B., 2006. Metodyka poboru prób zespołów fauny dennej w małych i średniej wielkości rzekach dla celów monitoringu ekologicznego zgodnego z założeniami RDW. Główny Inspektorat Ochrony Środowiska.

Bis, B. \& M. Wenikajtys, 2006. Metodyka poboru prób zespołów fauny dennej w wodach trudnodostępnych i dużych rzekach dla celów monitoringu ekologicznego zgodnego z założeniami RDW. Główny Inspektorat Ochrony Środowiska.

Bis, B., A. Zdanowicz \& M. Zalewski, 2000. Effects of catchment properties on hydrochemistry, habitat complexity and invertebrate community structure in a lowland river. Hydrobiologia 422(423): 369-387.

Błachuta, J., K. Czoch, K. Kulesza \& J. Picińska-Fałtynowicz, 2005. Typologia rzek i strumieni Polski. In: I Ogólnopolska Konferencja Naukowa. Wdrażanie Ramowej Dyrektywy Wodnej: ocena stanu ekologicznego wód w Polsce, 5-7.

Bona, F., E. Falasco, S. Fenoglio, L. Iorio \& G. Badino, 2008. Response of macroinvertebrate and diatom communities to human-induced physical alteration in mountain streams. River Research and Applications 24: 1068-1081.

Brittain, J. E., S. J. Saltveit, E. Castella, J. Bogen, T. E. Bønsnes, I. Blakar, T. Bremnes, I. Haug \& G. Velle, 2001. The macroinvertebrate communities of two contrasting Norwegian glacial rivers in relation to environmental variables. Freshwater Biology 46: 1723-1736.
Casado, C., L. Losada \& S. Mollá, 2011. Effect of special protected areas in the macroinvertebrate community in the Manzanares upper basin (Sierra de Guadarrama, Madrid). Limnetica 30(1): 71-88.

Clarke, K. D. \& D. A. Scruton, 1997. The benthic community of stream riffles in Newfoundland, Canada and its relationship to selected physical and chemical parameters. Journal of Freshwater Ecology 12(1): 113-121.

Clarke, R. T., J. F. Wright \& M. T. Furse, 2003. RIVPACS models for predicting the expected macroinvertebrate fauna and assessing the ecological quality of rivers. Ecological Modelling 160: 219-233.

Cortes, R. M. V., S. Varandas, S. J. Hughes \& M. T. Ferreira, 2008. Combining habitat and biological characterization: Ecological validation of the river habitat survey. Limnetica 27(1): 39-56.

Czerniawska-Kusza, I., 2005. Comparing modified biological monitoring working party score system and several biological indices based on macroinvertebrates for waterquality assessment. Limnologica 35: 169-176.

Dallas, H. F. \& Z. A. Ketley, 2011. Upper thermal limits of aquatic macroinvertebrates: comparing critical thermal maxima with $96-\mathrm{LT}_{50}$ values. Journal of Thermal Biology 36: 322-327.

Davy-Bowker, J., R. T. Clarke, R. K. Johnson, J. Kokes, J. F. Murphy \& S. Zahrádková, 2006. A comparison of the European Water Framework Directive physical typology and RIVPACS-type models as alternative methods of establishing reference conditions for benthic macroinvertebrates. Hydrobiologia 566: 91-105.

Directive, 2000/60/EC. Directive 2000/60/EC of the European Parliament and of the Council of 23 October 2000 Establishing a Framework for Community Action in the Field of Water Policy.

Dz. U., 2011. Dziennik Ustaw nr 257, poz. 1545. Rozporządzenie Ministra Środowiska z dnia 9 listopada $2011 \mathrm{r}$. w sprawie klasyfikacji stanu jednolitych części wód powierzchniowych oraz środowiskowych norm jakości dla substancji priorytetowych.

Eggers, T. O. \& A. Martens, 2001. A key to the freshwater Amphipoda (Crustacea) of Germany. Lauterbornia 42: 1-70.

Environment Agency, 2003. River Habitat Survey in Britain and Ireland. Field Survey Guidance Manual: 2003 Version.

Environment Agency, 2007. Hydromorfologiczna ocena wód płynących (River Habitat Survey). Poznań-Warrington.

Frutiger, A. \& G. Meier Buergisser, 2002. Life history variability of a grazing stream insect (Liponeura cinerascens minor; Diptera: Blephariceridae). Freshwater Biology 47: 1618-1632.

Gabriels, W., P. L. M. Goethals \& N. De Pauw, 2005. Implications of taxonomic modifications and alien species on biological water quality assessment as exemplified by the Belgian Biotic Index method. Hydrobiologia 542: 137-150.

Glöer, P., 2002. Mollusca I. Süsswassergastropoden. Nord- und Mitteleuropas Bestimmungsschlüssel, Lebensweise, Verbreitung. ConchBooks, Hackenheim.

Glöer, P. \& C. Meier-Brook, 2003. Süsswassermollusken. Ein Bestimmungsschlüssel für die Bundesrepublik Deutschland. Deutscher Jugendbund für Naturbeobachtung DJN, Hamburg. 
Gibbins, C. N., C. F. Dilks, R. Malcolm, C. Soulsby \& S. Juggins, 2001. Invertebrate communities and hydrological variation in Cairngorm mountain streams. Hydrobiologia 462: 205-219.

Haidekker, A. \& D. Hering, 2008. Relationship between benthic insects (Ephemeroptera, Plecoptera, Coleoptera, Trichoptera) and temperature in small and medium-sized streams in Germany: a multivariate study. Aquatic Ecology 42: 463-481.

Harding, J. S., E. F. Benfield, P. V. Bolstad, G. S. Helfman \& E. B. D. Jones, 1998. Stream biodiversity: The ghost of land use past. Proceedings of the National Academy of Sciences 95: 14843-14847.

Jacobsen, D., S. Rostgaard \& J. J. Vásconez, 2003. Are macroinvertebrates in high altitude streams affected by oxygen deficiency? Freshwater Biology 48: 2025-2032.

Jacobsen, D. \& R. Marín, 2008. Bolivian Altiplano streams with low richness of macroinvertebrates and large diel fluctuations in temperature and dissolved oxygen. Aquatic Ecology 42: 643-656.

Kołodziejczyk, A. \& P. Koperski, 2000. Bezkręgowce słodkowodne Polski. Klucz do oznaczania oraz podstawy biologii i ekologii makrofauny. Wydawnictwa Uniwersytetu Warszawskiego, Warszawa.

Kondracki, J., 2002. Geografia regionalna Polski. Wydawnictwo Naukowe PWN, Warszawa.

Kroll, S. A., C. Navarro Llacer, M. de la Cruz Cano \& J. de las Heras, 2009. The influence of land use on water quality and macroinvertebrate biotic indices in rivers within CastillaLa Mancha (Spain). Limnetica 28(2): 203-214.

Królak, E. \& M. Korycińska, 2008. Taxonomic composition of macroinvertebrates in the Liwiec River and its tributaries (Central and Eastern Poland) on the basis of chosen physical and chemical parameters of water and season. Polish Journal of Environmental Studies 17(1): 39-70.

Leunda, P. M., J. Oscoz, R. Miranda \& A. H. Ariño, 2009. Longitudinal and seasonal variation of the benthic macroinvertebrate community and biotic indices in an undisturbed Pyrenean river. Ecological Indicators 9: 52-63.

Lock, K., M. Asenova \& P. L. M. Goethals, 2011. Benthic macroinvertebrates as indicators of water quality in Bulgaria: a case study in the Iskar river basin. Limnologica 41(4): 334-338.

Maiolini, B. \& V. Lencioni, 2001. Longitudinal distribution of macroinvertebrate assemblages in a glacially influenced stream system in the Italian Alps. Freshwater Biology 46: 1625-1639.

Medhurst, R. B., M. S. Wipfli, C. Binckley, K. Polivka, P. F. Hessburg \& R. B. Salter, 2010. Headwater streams and forest management: does ecoregional context influence logging effects on benthic communities? Hydrobiologia 641: 71-83.

Miserendino, M. L., 2001. Macroinvertebrate assemblages in Andean Patagonian rivers and streams: environmental relationships. Hydrobiologia 444: 147-158.

Miserendino, M. L. \& L. A. Pizzolón, 2000. Macroinvertebrates of a fluvial system in Patagonia: altitudinal zonation and functional structure. Archiv für Hydrobiologie 150(1): $55-83$.

Mykrä, H., T. Saarinen, M. Tolkkinen, B. McFarland, H. Hämäläinen, K. Martinmäki \& B. Kløve, 2012. Spatial and temporal variability of diatom and macroinvertebrate communities: How representative are ecological classifications within a river system? Ecological Indicators 18: 208-217.

Nijboer, R. C., R. K. Johnson, P. F. M. Verdonschot, M. Sommerhäuser \& A. Buffagni, 2004. Establishing reference condition for European streams. Hydrobiologia 516: 91-105.

Péru, N. \& S. Dolédec, 2010. From compositional to functional biodiversity metrics in bioassessment: A case study using stream macroinvertebrate communities. Ecological Indicators 10: 1025-1036.

Piechocki, A., 2002. Gastropoda aquatica. Ślimaki wodne. In Głowaciński, Z. (ed.), Red List of Threatened Animals in Poland. Polish Academy of Sciences Institute of Nature Conservation, Cracow: 34-37.

Raven, P., N. Holmes, H. Dawson, A. Ławniczak, E. Bulánková, J. Topercer \& I. Lewin, 2011. River habitat and macrophyte surveys in the High Tatra Mountains of Slovakia and Poland. Results from 2010. A report. Environment Agency, UK.

Rawer-Jost, C., A. Zenkert \& J. Böhmer, 2004. Reference conditions of German stream types analysed and revised with macroinvertebrate fauna. Limnologica 34: 390-397.

Rozkošný, R., 1980. Klíč vodních larev hmyzu. Československá Academie VĚD, Praha.

Sánchez-Montoya, M. M., M. R. Vidal-Abarca, T. Puntí, J. M. Poquet, N. Prat, M. Rieradevall, J. Alba-Tercedor, C. Zamora-Muñoz, M. Toro, S. Robles, M. Álvarez \& M. L. Suárez, 2009. Defining criteria to select reference sites in Mediterranean streams. Hydrobiologia 619: 39-54.

Sánchez-Montoya, M. M., M. R. Vidal-Abarca \& M. L. Suárez, 2010. Comparing the sensitivity of diverse macroinvertebrate metrics to a multiple stressor gradient in Mediterranean streams and its influence on the assessment of ecological status. Ecological Indicators 10: 896-904.

Sandin, L., 2003. Benthic macroinvertebrates in Swedish streams: community structure, taxon richness, and environmental relations. Ecography 26: 269-282.

Sandin, L. \& R. K. Johnson, 2000a. The statistical power of selected indicator metrics using macroinvertebrates for assessing acidification and eutrophication of running waters. Hydrobiologia 422(423): 233-243.

Sandin, L. \& R. K. Johnson, 2000b. Ecoregions and benthic macroinvertebrate assemblages of Swedish streams. Journal of the North American Benthological Society 19(3): 462-474.

Semenchenko, V. P. \& M. D. Moroz, 2005. Comparative analysis of biotic indices in the monitoring system of running water in a biospheric reserve. Water Resources 32(2): 200-203.

Szoszkiewicz, K., A. Buffagni, J. Davy-Bowker, J. Lesny, B. H. Chojnacki, J. Zbierska, R. Staniszewski \& T. Zgoła, 2006. Occurrence and variability of River Habitat Survey features across Europe and the consequences for data collection and evaluation. Hydrobiologia 566: 267-280.

Szoszkiewicz, K., J. Zbierska, S. Jusik \& T. Zgoła, 2010a. Makrofitowa Metoda Oceny Rzek. Podręcznik Metodyczny do oceny i klasyfikacji stanu ekologicznego wód płynących w oparciu o rośliny wodne. Bogucki Wydawnictwo Naukowe, Poznań. 
Szoszkiewicz, K., S. Jusik, A. E. Lawniczak \& T. Zgoła, 2010 b. Macrophyte development in unipacted lowland rivers in Poland. Hydrobiologia 656: 117-131.

Šporka, F., H. E. Vlek, E. Bulánková \& I. Krno, 2006. Influence of seasonal variation on bioassessment of streams using macroinvertebrates. Hydrobiologia 566: 543-555.

Šporka, F., Z. Pastuchová, L. Hamerlík, M. Dobiašová \& P. Beracko, 2009. Assessment of running waters (Slovakia) using benthic macroinvertebrates - derivation of ecological quality classes with respect to altitudinal gradients. Biologia 64(6): 1196-1205.

Ter Braak, C. J. F. \& P. Šmilauer, 2002. CANOCO Reference manual and CanoDraw for Windows User's Guide: Software for Canonical Community Ordination (version 4.5). Microcomputer Power Ithaca, NY, USA.

Torrissi, M., S. Scuri, A. Dell'Uomo \& M. Cocchioni, 2010. Comparative monitoring by means of diatoms, macroinvertebrates and chemical parameters of an Apennine watercourse of central Italy: The River Tenna. Ecological Indicators 10: 910-913.

Tripole, S., E. A. Vallania \& M. C. Corigliano, 2008. Benthic macroinvertebrate tolerance to water acidity in the Grande river sub-basin (San Luis, Argentina). Limnetica 27(1): 29-38.
Verdonschot, P. F. M., 2006. Evaluation of the use of Water Framework Directive typology descriptors, reference sites and spatial scale in macroinvertebrate stream typology. Hydrobiologia 566: 39-58.

Vlek, H. E., P. F. M. Verdonschot \& R. C. Nijboer, 2004. Towards multimetric index for the assessment of Dutch stream using benthic macroinvertebrates. Hydrobiologia 516: 173-189.

Walker, J., M. Diamond \& M. Naura, 2002. The development of physical quality objectives for rivers in England and Wales. Aquatic Conservation: Marine and Freshwater Ecosystems 12: 381-390.

Wyżga, B., P. Oglęcki, A. Radecki-Pawlik, T. Skalski \& J. Zawiejska, 2012. Hydromorphological complexity as a driver of the diversity of benthic invertebrate communities in the Czarny Dunajec River, Polish Carpathians. Hydrobiologia 696: 29-46.

Wyżga, B., P. Oglęcki, H. Hajdukiewicz, J. Zawiejska, A. Radecki-Pawlik, T. Skalski \& P. Mikuś, in press. Interpretation of the invertebrate-based BMWP-PL index in a gravel-bed river: insight from the Polish Carpathians. Hydrobiologia. doi:10.1007/s10750-012-1280-0. 